REGARDS

SUR LECONOMIE ALLEMANDE

BULLETIN ECONOMIQUE DU CIRAC

\section{Regards sur l'économie allemande}

Bulletin économique du CIRAC

$68 \mid 2004$

Varia

\title{
Management culturel
}

HEINZE Thomas (ed.), Neue Ansätze im Kulturmanagement. Theorie und Praxis

\section{(2) OpenEdition}

Journals

Édition électronique

URL : http://journals.openedition.org/rea/3645

DOI : $10.4000 /$ rea.3645

ISBN : 978-2-8218-0832-4

ISSN : $1965-0787$

Éditeur

CIRAC

Édition imprimée

Date de publication : 1 octobre 2004

ISSN : 1156-8992

Référence électronique

" Management culturel », Regards sur l'économie allemande [En ligne], 68 | octobre 2004, mis en ligne le 29 avril 2009, consulté le 22 septembre 2020. URL : http://journals.openedition.org/rea/3645 ; DOI : https://doi.org/10.4000/rea.3645

Ce document a été généré automatiquement le 22 septembre 2020

(C) CIRAC 


\section{Management culturel}

HEINZE Thomas (ed.), Neue Ansätze im Kulturmanagement. Theorie und Praxis

\section{RÉFÉRENCE}

HEINZE Thomas (ed.), Neue Ansätze im Kulturmanagement. Theorie und Praxis, VS Verlag für Sozialwissenschaften, Wiesbaden, 2004, 256 p.

1 Dans le contexte des restrictions budgétaires, le secteur culturel est soumis lui aussi, aujourd'hui, à une profonde modernisation. Les techniques modernes de management, de certification (normes ISO qualité) ou de gestion y font leur entrée. Manuel théorique et pratique de cette nouvelle discipline qu'est le management culturel. (ib) 